Draft of chapter to appear in: The Psychology of Natural Kinds Terms. In S.T. Biggs, \& H. Geirsson (Eds.) The Routledge Handbook on Linguistic Reference. London: Routledge.

\author{
The psychology of natural kind terms \\ Emily Foster-Hanson \& Marjorie Rhodes \\ New York University
}

Funding. This chapter was supported by National Science Foundation grant BCS 1729540 (to M.R.) and by the Eunice Kennedy Shriver National Institute of Child Health \& Human Development of the National Institutes of Health under Award Number F31HD093431 (to E.F.H.). The content is solely the responsibility of the authors and does not necessarily represent the official views of the National Institutes of Health. 


\section{The psychology of natural kind terms}

When he was three years old, the child of one of the authors came running into the living room to proclaim to her, "I know the dolphins in daddy's closet are really mammaldolphins, like you said, and they breathe outside of water. But they look like fish-dolphins, so I'm going to pretend that's what they are."

There were no dolphins in the closet-not real ones, not toys, not pictures. They existed only in his imagination. But even in his imagination, this three-year-old child did not treat the categories of fish, mammal, or dolphin as arbitrary. His words signaled that he viewed these categories as real, objective facts about the world. He accepted that whether a dolphin was a fish or mammal was not a matter of his opinion (or something he could figure out by relying on his own perception), but a matter decided by experts. His beliefs were so firm about this that he couldn't think otherwise-even in his imagination-without signaling that he knew he was doing so "only for pretend."

In this example, the child used the words, "dolphin," "fish," and "mammal" as natural kind terms-words that speakers and listeners understand as referring to categories that they view as natural kinds. Not all category labels are natural kind terms because not all categories are natural kinds. Some are groupings that people agree are a matter of choice. For example, people can disagree over whether a hotdog is a sandwich, a beanbag is a chair, or whether sugar-free cookies belong in the category of diet foods (Gelman \& Coley, 1991; Malt, 1990). Natural kind terms, in contrast, refer to those categories that we believe "carve nature at its joints" (Plato 380 B.C./1974; Mill, 1884; e.g., Kripke, 1972; Putnam, 1973, 1975a; Quine, 1977; Schwartz, 1979; Wilson, 1999). From this perspective, grouping things into these kinds of categories is a matter of discovering these joints, not creating them. These intuitions are often wrong (Gelman \& Rhodes, 2012; Mayr, 1982; Leslie, 2013; Shtulman, 2017), but their implications for psychology, linguistics, and conceptual development are profound. In this chapter, we 
review what it means to think of a category as a natural kind, how natural kind terms get their status in psychology and language, and how the language of natural kinds shapes cognition, development, and behavior.

\section{Categories as natural kinds}

The prototypical example of a category that people think of as a natural kind is a basic level species (e.g., tiger, rose, bee). In contrast to other types of groupings (e.g., ad-hoc categories, goal-directed groups, and even categories of human-made artifacts), people's conceptual representations of natural kinds are distinctive in several ways (Gelman \& Coley, 1991). As illustrated in the above example, people think that the boundaries of these categories are set by nature, and therefore are an objective matter of fact, not up to individual opinion. Following what Putnam described as the division of linguistic labor (1973), people think it is reasonable to say, "according to experts, that's a planet," but not "according to experts, that's a toy," because we rely on experts to figure out the status of celestial bodies (whose status we view as set by nature and discovered by humans) but not to figure out the status of a toy (which could be whatever a child chooses to play with; Malt, 1990). Similarly, people think that there are many flexible and subjective ways to classify human-made artifacts but only one correct, objective (natural) way of classifying animals (Kalish, 1998; Rhodes \& Gelman, 2009a).

People also think that natural kinds have absolute boundaries: Even an unusual bird (e.g., a penguin) is still fully a bird, but an unusual piece of furniture (e.g., a beanbag) can be "sort of" a chair (Diesendruck \& Gelman, 1999; Estes, 2003, 2004; Kalish, 2002; Rhodes \& Gelman, 2009b). As another consequence of thinking of natural kinds as carving nature at its joints, people think of these categories as capturing fundamental patterns of similarities and differences_-that members of the same kind are deeply similar to each other and different from others in many observable and unobservable ways. Thus, people readily generalize the features of individual members of natural kinds to other members of their categories, more than they do 
for other types of groupings (Gelman, 1988; Gelman \& O’Reilly, 1988; Rips, 1975).

Finally, people expect membership in natural kind categories (e.g., whether an individual animal is a tiger) to be stable, even across superficial transformations (e.g., if someone paints over its stripes; Gelman \& Wellman, 1991; Keil, 1989) and changes in environment (e.g., it grows up in a community of peaceful sheep; Gelman \& Wellman, 1991; Waxman, Medin, \& Ross, 2007).

It feels like we discover natural kinds in the world, and that the reason we think of some categories this way (e.g., animal species) more than others (e.g., human-made artifacts) is because of the objective structure of nature-that the world of animals simply is composed of discrete and homogeneous natural kinds while the world of artifacts is not. But this is not the case. The distinction between natural kinds and other types of categories is psychological. This is illustrated by two key considerations. First, whether we construe a particular category as a natural kind is not entirely dependent on its ontological status. It might feel like the objective structure of the world dictates that there is one correct answer to whether Pluto is a planet but reasonable disagreement over whether a hotdog is a sandwich, yet these intuitions both originate in human culture. This is partly because people rely on experts to determine the boundaries of natural kinds, but even experts can be wrong (and in fact, the scientific method relies on experts constantly updating their beliefs). The subjective nature of natural kinds is clear because people vary in which categories they view as natural kinds. People in most (but not all; Astuti, 1995) cultures studied to date think of basic level species categories as natural kinds-as having objective, discrete boundaries and picking out coherent, homogeneous categories (Atran, 1990; Taverna, Medin, \& Waxman, 2016). Even in the biological domain, however, beliefs about the status of particular categories varies by experience (Medin et al., 2006; Medin, Waxman, Woodring, \& Washinawatok, 2010; Ross, Medin, Coley, \& Atran, 2003) and expertise (Bailenson et al., 2002; Burnett, Medin, Ross, \& Block, 2005; Lynch, Coley, \& Medin, 2000; Medin, Ross, Atran, Burnett, \& Blok, 2002). For example, most diners don't realize 
that when they order "grouper" from a restaurant menu, they could be served any of what the U.S. Food and Drug Administration considers to be 64 different species of fish (Lowell, Mustain, Ortenzi, \& Warner, 2015).

Second, our intuitions about natural kinds are incompatible with modern views of the structure of the world. Even basic level animal species-the prototypical example of natural kinds-do not have the type of absolute, objective, and stable boundaries that people usually think they do, nor do they reliably pick-out categories are that are highly homogeneous and distinct from other kinds of things (Gelman, 2003; Leslie, 2013, see also Kalish, 1998). For example, different species like polar bears and grizzly bears sometimes breed in nature, resulting in hybrids that are "sort of" members of both kinds (Mallet, 2008). While sometimes our intuitions about animal species will fit with reality as we experience it (e.g., an animal will still be a ferocious tiger if we paint over its stripes), these intuitions are cognitive shortcuts and are misleading in a broader sense (e.g., species boundaries change over evolutionary time: Gelman \& Rhodes, 2012). In this way, natural kinds are a psychological, not a metaphysical, realitythey are a very important type of psychological concepts, but a confusing and misleading construct in any theory of biology or metaphysics.

Variability in natural kind beliefs is particularly striking in how people represent different social divisions. For instance, some people represent race as a natural kind-and think that race is a fundamental and objective way of categorizing people-whereas others understand it as a social construction (Rhodes \& Gelman, 2009a). How people view race and ethnicity varies by their own political views (Mandalaywala, Amodio, \& Rhodes, 2017; and for children, those of their parents; Rhodes \& Gelman, 2009a), the diversity of their local environment (Deeb, Segall, Birnbaum, Ben-Eliyahu, \& Diesendruk, 2011; Mandalaywayla, Ranger-Murdock, Amodio, \& Rhodes, 2018), and their own membership in a majority or minority group (Kinzler \& Dautel, 2011; Mandalaywala et al., 2018; Roberts \& Gelman, 2016). Similarly, whether people think of religion as marking natural kinds depends on their own religious upbringing (Chalik, Leslie, \& 
Rhodes, 2017; Diesendruck \& Haber, 2009) and whether religion is associated with social and political conflict in their environment (Diesenruck, Goldfein-Elbaz, Rhodes, Gelman, \& Neumark, 2013; Smyth et al., 2017). Even gender, which people often think of as the prototypical example of a natural kind division in the social world (Rothbart \& Taylor, 1992; Prentice \& Miller, 2007; Taylor, 1996; Taylor, Rhodes, \& Gelman, 2009a), is understood by some to be socially constructed and arbitrary (Fast \& Olson, 2018;

Rhodes \& Gelman, 2009a). Representations of social categories illustrate several key things of natural kind beliefs: They are inaccurate (in none of these cases does a natural kind representation accurately reflect the objective structure of the social world), but they are also pervasive, variable, and potentially highly problematic (as will be discussed in more detail below).

\section{How natural kinds get their status in psychology and language}

Given that natural kinds are psychologically created, there are two related questions about how they get their status in psychology and language. First: Where does the tendency to think of some categories as marking natural kinds come from? That is, if natural kind representations are inaccurate, why do people have them? Second: Why do people come to represent some particular categories (and not others) in this way?

\section{Where do natural kind representations come from?}

One might think that natural kind beliefs arise as a product of formal science instruction or other aspects of western education. It seems natural to assume that learning taxonomic systems of categorization, about DNA, and so on, could lead to the development of these beliefs. For example, learning about how genes are passed from parents to offspring provides an intuitive framework through which people might think of a wide range of properties-from skin color to musical talent-as heritable and fixed. 
Indeed, many biology curricula reinforce thinking of the biological world as composed of natural kinds, often to the detriment of students' conceptual understanding of the processes that underlie evolution, the consequences of climate change, and other important scientific concepts (Bean, Sinatra, \& Schrader, 2010; Donovan, 2013; Short \& Hawley, 2015; Shtulman \& Calabi, 2013; Shtulman, 2017; Swiney, Bates, \& Coley, 2018).

But, although some curricula do (perhaps inadvertently) reinforce natural kind representations, formal education does not create them. Natural kind representations of the biological world develop even in cultures with diverse educational practices and even with little exposure to formal science instruction at all (Atran, 1990; Taverna et al., 2016). Further, these beliefs develop in children prior to the onset of formal schooling (Gelman \& Kremer, 1991; Gelman \& Wellman, 1991; Waxman, Medin, \& Ross, 2007). For example, before the age of 6, children think that people might disagree over how to categorize human-made artifacts but that there is only one objectively accurate way to classify animals (Rhodes \& Gelman, 2009a; Rhodes, Gelman, \& Karuza, 2014; Diesendruck et al., 2013). Young children are also certain than a penguin is either $100 \%$ a bird or not a bird at all (even if they aren't sure which) but agree that sunglasses are "sort of" clothing, for example. Finally, young children expect babies born to tiger parents to grow up to be ferocious tigers no matter what they look like or how they are raised (Gelman \& Wellman, 1991; Keil, 1989), and they expect members of basic level species categories to share fundamental properties, even if they look different from one another (Gelman \& Markman, 1986; Gelman, 1988).

Young children across diverse cultural contexts hold these natural kind beliefs not only about animal species, but also about human gender categories (Rhodes \& Gelman, 2009a) and other social divisions that are salient in their environment (Diesendruck, Goldfein-Elbaz, Rhodes, Gelman, \& Neumark, 2013; Diesendruck \& Haber, 2009; Mandalaywala et al., 2017; Smyth et al., 2017). For example, children think it is objectively accurate to categorize people as boys or girls (Rhodes \& Gelman, 2009; Diesendruck et al., 2013), and they think that girls 
have many features in common with one another despite differences in appearance, personality, or preferences (Berndt \& Heller, 1986; Biernat, 1991; Gelman, Maccoby, \& Markman, 1986; Taylor, Rhodes, \& Gelman, 2009). Young children sometimes hold these beliefs even in communities where adults have more flexible beliefs (Astuti et al., 2004; Rhodes \& Gelman, 2009a).

That natural kind representations emerge so early in children's development suggests that they are the product of fundamental and basic conceptual biases, rather than the result of direct instruction (Gelman, 2003; Rhodes \& Mandalaywala, 2017). Children rely on basic conceptual and explanatory biases to actively construct their understanding of the world (Wellman \& Gelman, 1992; Gopnik \& Wellman, 2012). In the course of this process, they use basic perceptual and conceptual processes to categorize entities into distinct groups (e.g., to distinguish tigers from wolves) and basic explanatory biases to make sense of the patterns they observe (e.g., after observing that tigers have stripes and wolves do not, they could assume that there is something intrinsic to tigers and wolves that explains these differences; Cimpian \& Steinberg, 2014; Cimpian \& Solomon, 2014). The process of observing and explaining clusters of properties (e.g., having stripes, being orange, etc.) can also lead children to develop higher-order beliefs about the structure of the category-to assume that because tigers and wolves differ in several obvious ways, they probably differ in other ways not yet discovered as well, and that these differences are generally caused by intrinsic mechanisms (even if it isn't yet clear what those are).

Finally, children can then develop beliefs at still higher levels of abstractionwherein after learning about tigers, wolves, birds, monkeys and so on, they then assume that the biological domain—in general—is composed of natural kinds. This abstract framework theory about the structure of the domain can then guide how they represent and think about new species categories as they encounter them. Indeed, by age 4 , 
children hold domain-specific hypotheses about the structure of categories: They expect animal categories, in general, to be natural kinds (Gelman \& Markman, 1986; Keil, 1989), but they recognize that social categories have more variable structure, and not all groupings of people reflect deep homogeneity across members (Diesendruck et al., 2013; Rhodes \& Gelman, 2009; Kalish \& Lawson, 2008). Importantly, natural kind beliefs describe a set of inter-related beliefs about the structure of categories (e.g., homogeneity, stability, fixed boundaries, and so on) which can operate in different ways across categories and domains (Noyes \& Dunham, 2019; Rhodes \& Mandalaywala, 2017).

\section{Why do people come to represent any particular category as a natural kind?}

Although children do not need to be explicitly taught that a particularly category is a natural kind, the processes by which they identify particular categories (or domains of categories) as natural kinds are highly sensitive to testimony from others and embedded in culture (Butler \& Markman, 2012; Butler \& Tomasello, 2016; Callanan, 1990; Gelman, 2009;

Gelman, Ware, Manczak, \& Graham, 2013; Csibra \& Gergely, 2009; Harris \& Koenig, 2006). Just as adults defer to experts to know the "true" status of natural kind categories (Malt, 1990), children look to the experts in their communities (i.e., adults) to learn how to divide up the world into meaningful units of experience (Danovich \& Keil, 2004; Gelman \& Markman, 1986; Jaswal, 2010; Jaswal, Lima, \& Small, 2009; Noyes \& Keil, 2017; VanderBorght \& Jaswal, 2009; Wilson \& Keil, 1998).

Language plays a powerful role in shaping these processes (Vygostsky, 1962; Quine, 1977). For example, labels mark categories as distinct kinds of things (Kripke, 1972, Putnam, 1973, 1975a). Hearing noun labels helps even 3-month-old infants group objects into categories (Fulkerson \& Waxman, 2007; Waxman \& Hall, 1993; Xu, 2002). For example, young babies who see perceptually dissimilar members of a category (e.g., fish), categorize them into the same 
group if they are presented with the same label (e.g., "Look at this toma!"), but not otherwise (Ferry, Hespos, \& Waxman, 2010). Labels facilitate categorization because they are reliable cues of the speaker's intent to communicate that individuals are similar in some meaningful way (Ferguson \& Lew-Williams, 2016). While labels facilitate categorization, many labeled categories (e.g., toys, hammers, crackers) are not represented as natural kinds. Thus, simply being used as a category label does not turn a noun into a natural kind term.

Using labels to provide generic descriptions of categories, however, may begin to do so (Carlson, 1977; Gelman, 2003; Leslie, 2008). Generic statements (e.g., "birds lay eggs", "girls wear pink") describe the properties of abstract categories, in contrast with quantified statements about specific category members (e.g., "these birds lay eggs," “Anna wears pink”; Carlson \& Pelletier, 1995). By at least 30 months, children understand generics to describe abstract categories, instead of particular examples. For example, upon looking at a picture of two penguins, 2-year-old children respond "no" when they are asked, "Do these birds fly?" but "yes" (when looking at the same picture), when they are asked "Do birds fly?" (Gelman \& Raman, 2003; Graham, Nayer, \& Gelman, 2011; Hollander, Gelman, \& Star, 2002; Rhodes, Leslie, Bianchi, \& Chalik, 2017). Thus, by age two, children can track the difference between generic, abstract references to categories and references to particular members. By age three (and perhaps earlier), children also recognize generics as describing generalizable information about what category members are usually like, and they expect that the properties described by generics are common across category members (Cimpian, Brandone, \& Gelman, 2010; Leslie, Khemlani, Glucksberg, 2011), even when this is not always the case (for instance, the statement, "mosquitos carry the west Nile virus" is true of less than $1 \%$ of mosquitos, yet it can still be expressed generically). 
Thus, within the first few years of life, children understand that generic statements communicate generalizable information about abstract categories. Generics communicate information about shared properties, which can trigger the processes of developing higher-order beliefs (e.g., that tigers have a lot in common in general), as well as explanatory assumptions that these patterns probably reflect intrinsic causes, as described above. Critically, children also defer to the expertise of adult speakers to use generics to signal that the category of interest is the type of category that carves nature at its joints. When an adult says, "Tigers have stripes," "Tigers are ferocious," "Tigers run very fast", children learn not only about three features of tigers, they also learn that a knowledgeable adult in their community thinks that tigers is a meaningful way of dividing up the natural world. Thus, via multiple mechanisms, generic language contributes to the development of natural kind beliefs. Once a particular category label is described with generics, it can begin to take on the status of a natural kind term.

For generics to play this role in the creation of natural kind beliefs and natural kind terms, and to account for the culturally variable spread of natural kind beliefs about particular groupings, then two things must be true. First, hearing categories described with generics must trigger the formation of natural kind beliefs in people (including in young children), and second, knowledgeable speakers (including teachers and parents) must produce such generics for categories for which they themselves hold these representations. If so, generic language would serve as a vehicle by which natural kind beliefs about particular categories spread across communities.

There is indeed empirical support for both of these processes. First, generic language leads labels to take on the status of natural kind terms (in other words, hearing them elicits natural kind beliefs about referenced categories). Even hearing just a small number of generic statements about new categories of animals or people leads children and adults to view them as more homogeneous, stable, and causally powerful than they would otherwise (Gelman, Ware, \& Kleinberg, 2010; Rhodes, Leslie, \& Tworeck, 2012). For example, hearing a series of generic 
statements about a new category (e.g., "Zarpies love to eat flowers," "Zarpies flap their arms when they're happy," and so on) leads people to think that Zarpies represents a meaningful kind and that individual Zarpies will share many other features that were not mentioned. Indeed, even 2-year-old children form new social categories (i.e., they can identify members of the category Zarpies) when they hear both noun labels and generics (e.g., "Zarpies eat flowers"), but not when they hear noun labels alone (e.g., "This Zarpie eats flowers; Rhodes, Leslie, Bianchi, \& Chalik, 2017; Rhodes, Leslie, \& Tworeck, 2012).

Second, the production of generic language reflects speakers' beliefs. Speakers use more generics when talking about categories they view as natural kinds (e.g., animal kinds, gender categories) than about categories they do not view in this way (e.g., artifacts; Brandone \& Gelman, 2009; Gelman, Goetz, Sarnecka, \& Flukes, 2008; Gelman, Taylor, \& Ngyuen, 2004; Goldin-Meadow, Gelman, \& Mylander, 2005; Pappas \& Gelman, 1998; Segall, Birnbaum, Deeb, \& Diesendruck, 2015). Inducing beliefs that a category is a natural kind even leads people to describe it using more generics (Rhodes et al., 2012). And this type of input is ubiquitous: Generics are frequent in parent-child conversations (Gelman, Goetz, Sarnecka, \& Flukes, 2008; Graham, Nayer, \& Gelman, 2011) and—like natural kind concepts—across languages (Pirahã: Everett, 2009; Spanish: Gelman, Sánchez Tapia, \& Leslie, 2016; Quechua: Mannheim, Gelman, Escalante, Huayhua, \& Puma, 2010; Mandarin: Tardif, Gelman, Fu, \& Zhu, 2012). Thus, children hear knowledgeable speakers use generics to communicate their natural kind beliefs in their daily lives, and hearing categories described with generics triggers the formation of natural kind beliefs. In this way, generic language serves as a powerful tool for communicating natural kind beliefs about particular categories across communities.

As described above, one way that generic language shapes beliefs that a particular category is meaningful and distinct is by communicating that a knowledgeable speaker thinks it is. In order to understand what people mean when they talk, listeners 
engage in complex calculations about a speaker's knowledge state and the set of relevant alternatives—-the things the speaker could have said but chose not to (Clark, 1996; Grice; 1975; Horn, 1984). To the extent that a set of other possibilities is salient in the communicative context (e.g., a knowledgeable speaker clearly could have generalized about children, but instead chose to generalize only about girls), the choice to use a generic to talk about a particular grouping is in itself informative. In support of this account, children infer that categories that a knowledgeable speaker describes with generics denote natural kinds, even if the particular properties the generics assert about the category later turn out to be wrong (Foster-Hanson, Leslie, \& Rhodes, 2019; see also Moty \& Rhodes, 2019).

\section{How the language of natural kinds shapes cognition, development, and behavior}

Once people come to think of a particular category as a natural kind, these beliefs have a range of consequences for how they use that category in their daily lives. As described above, people use natural kinds to generalize information to new kind members (Gelman, 1988; Gelman \& O’Reilly, 1988; Rips, 1975), to infer fixed category boundaries (Diesendruck \& Gelman, 1999; Estes, 2003, 2004; Kalish, 2002; Rhodes \& Gelman, 2009b), and to reason about heritability (Gelman \& Wellman, 1991; Waxman, Medin, \& Ross, 2007). While these inferences provide useful cognitive shortcuts and can simplify learning, people's inferences about natural kinds can also be problematic. For example, beliefs that animal kinds are homogenous and discrete are at odds with modern views of evolutionary change (Gelman \& Rhodes, 2012; Mayr, 1982) and can lead people to ignore category variability (Emmons \& Kelemen, 2015; Shtulman \& Shultz, 2008). Thinking of animal categories as stable can even impede people's ability to understand processes like metamorphosis (French, Menendez, Herrmann, Evans, \& Rosengren, 2018). 
Thinking of human social categories (e.g., gender, race, or religion) as objectively true can be particularly troublesome, as such groupings are often determined by history and cultural convention, rather than the objective structure of the world (Hirschfield, 1996). For instance, thinking of race as a natural kind is associated with more prejudice towards Black people and more endorsement of existing social hierarchies (Mandalaywala, Amodio, \& Rhodes, 2017; Williams \& Eberhardt, 2008). Adults' beliefs that gender categories reflect the objective structure of the world are also correlated with more endorsement of gender stereotypes (Brescoll \& LaFrance, 2004; Brescoll, Uhlmann, \& Newman, 2013) and more support for boundary-enhancing initiatives like laws mandating that transgender people use restrooms corresponding to their biological sex (Roberts, Ho, Rhodes, \& Gelman, 2017). Inducing essentialist beliefs about novel social categories even leads 4- to 6-year-old children to share fewer resources with them (Rhodes, Leslie, Saunders, Dunham, \& Cimpian, 2017).

Describing behaviors that children are familiar with using category labels (e.g., "helpers", "drawers") can even shape their attitudes and behavior (Cimpian, Arce, \& Markman, 2007; Foster-Hanson, Cimpian, Leshin, \& Rhodes, 2018; see also Gelman \& Heyman, 1999). Finally, hearing categories described using generics leads young children to infer not only what category members usually are like, but also what they should be like, and to say it's wrong to do things differently from the group (Roberts, Ho, \& Gelman, 2017).

\section{Other interpretations of generics}

While generics can communicate natural kind beliefs, they communicate other information and are open to alternate interpretations as well. For instance, generics also communicate information about the prevalence of particular properties (Cimpian, 
Brandone, \& Gelman, 2010), as people assume that the properties described by generics are more prevalent for the referenced category than for other similar categories (Tessler \& Goodman, 2019).

More broadly, people's concepts are situated within causal frameworks about the structure of the world (Murphy \& Medin, 1985). Thus, people interpret generic claims about categories in the context of their previous expectations about the structure of the category and the domain. In some cases, for example, people might have expectations that categoryregularities are not caused by intrinsic mechanisms, but instead result from extrinsic or structural forces (Vasilyeva, Gopnik, \& Lombrozo, 2018). For example, some people might assume that "girls wear pink" because girls naturally love pink (an intrinsic cause) whereas others might assume that this is because stores mostly sell pink clothes for girls (a structural cause). When people have these structure-based beliefs, generic descriptions are unlikely to elicit natural kind representations.

Thus, whether generics lead people to think of category labels as natural kind terms does not depend on the language alone, but on how it interacts with their developing conceptual frameworks. As described above, a critical component of these frameworks is whether people think that category regularities are explainable by intrinsic or structural causes. While children can understand structural explanations when they are given (Vasilyeva et al., 2018), they are harder for children to generate on their own. For example, structural causes are often not readily observable, and understanding them relies on relational reasoning (Gentner 1983, 2005; Richland, Morrison, \& Holyoak, 2006) and thinking counterfactually about how things could have been (Beck, Robinson, Carroll, \& Apperly, 2006; Rafetseder, Cristi-Vargas, \& Perner, 2010), both capacities that emerge relatively late in development. In contrast, internal causes for category regularities are often easier for people to learn and bring to mind (Cimpian \& Solomon, 2014; Hussak \& Cimpian, 2018). A preference for intrinsic causes may even be a basic cognitive bias: Young infants often infer internal causes when no external causes are apparent 
(Gelman, 1990; Premack, 1990; Spelke, Phillips, \& Woodward, 1995; Stewart, 1984).

Thus, understanding generics as describing the underlying nature of categories appears to be a cognitive bias (Cimpian \& Cadena, 2010; Cimpian \& Markman, 2011; Gelman, 2004; Leslie, 2014; Lyons, 1977; Prasada \& Dillingham, 2009), although possibly one that varies by culture (Carstensen, Zhang, Heyman, Fu, Lee, \& Walker, 2019; see also Choi, Nisbett, \& Norenzayan, 1999).

\section{Concluding thoughts}

In summary, natural kind terms refer to natural kinds-categories that people think are objectively true, but that in fact reflect a psychological—rather than a metaphysical—reality. People communicate their beliefs about which categories are natural kinds through the way they talk, especially by describing categories using generic noun phrases like, "Tigers have stripes," Gold is a precious metal," and "Boys just like to get messy." Once people come to see a category as a natural kind, these beliefs shape their cognition and behavior in a variety of ways, some of which (e.g., stereotyping and prejudice) can be harmful. Given the many ways that natural kind terms shape how people think and act, understanding how they are transmitted across cultures and generations is therefore crucial to the study of human thought.

Author Note. Preparation of this chapter was supported by the Eunice Kennedy Shriver National Institute of Child Health \& Human Development of the National Institutes of Health under Award Number R01HD087672 (to Rhodes) and F31HD093431 (to Foster-Hanson).The content is solely the responsibility of the authors and does not necessarily represent the official views of the National Institutes of Health. 


\section{References}

Atran, S. (1990). Cognitive foundations of natural history: Towards an anthropology of science. New York: Cambridge University Press.

Astuti, R. (1995). People of the Sea: Identity and Descent among the Vezo of Madagascar (No. 95). Cambridge University Press.

Astuti, R., Gregg E. A. Solomon, Carey, S., Ingold, T., \& Miller, P. (2004). Constraints on Conceptual Development: A Case Study of the Acquisition of Folkbiological and Folksociological Knowledge in Madagascar. Monographs of the Society for Research in Child Development, 69(3), I-161.

Bailenson, J. N., Shum, M. S., Atran, S., Medin, D. L., \& Coley, J. D. (2002). A bird's eye view: Biological categorization and reasoning within and across cultures. Cognition, 84(1), 153. https://doi.org/10.1016/S0010-0277(02)00011-2

Bean, T. E., Sinatra, G. M., \& Schrader, P. G. (2010). Spore: Spawning evolutionary misconceptions?. Journal of Science Education and Technology, 19(5), 409-414. https://doi.org/10.1007/s10956-010-9211-1

Beck, S. R., Robinson, E. J., Carroll, D. J., \& Apperly, I. A. (2006). Children's thinking about counterfactuals and future hypotheticals as possibilities. Child Development, 77(2), 413426. https://doi.org/10.1111/j.1467-8624.2006.00879.x

Berndt, T. J., \& Heller, K. A. (1986). Gender stereotypes and social inferences: A developmental study. Journal of Personality and Social Psychology, 50(5), 889898. https://doi.org/10.1037/0022-3514.50.5.889 
Biernat, M., Manis, M., \& Nelson, T. E. (1991). Stereotypes and standards of judgment. Journal of Personality and Social Psychology, 60(4), 485-499. https://doi.org/10.1037/00223514.60.4.485

Brandone, A. C., \& Gelman, S. A. (2009). Differences in preschoolers' and adults' use of generics about novel animals and artifacts: A window onto a conceptual divide. Cognition, 110(1), 1-22. https://doi.org/10.1016/j.cognition.2008.08.005

Brescoll, V. L., Uhlmann, E. L., \& Newman, G. E. (2013). The effects of system-justifying motives on endorsement of essentialist explanations for gender differences. Journal of Personality and Social Psychology, 105(6), 891. https://doi.org/10.1037/a0034701

Brescoll, V., \& LaFrance, M. (2004). The correlates and consequences of newspaper reports of research on sex differences. Psychological Science, 15(8), 515-520. https://doi.org/10.1111/j.0956-7976.2004.00712.x

Burnett, R. C., Medin, D. L., Ross, N. O., \& Blok, S. V. (2005). Ideal is typical. Canadian Journal of Experimental Psychology/Revue Canadienne de Psychologie Expérimentale, 59(1), 310. https://doi.org/10.1037/h0087453

Butler, L. P., \& Markman, E. M. (2012). Preschoolers use intentional and pedagogical cues to guide inductive inferences and exploration. Child Development, 83, 1416-1428. https://doi.org/10.1111/j.1467-8624.2012.01775.x

Butler, L. P., \& Tomasello, M. (2016). Two- and 3-year-old children integrate linguistic and pedagogical cues in guiding inductive generalizations and exploration. Journal of Experimental Child Psychology, 145, 64-78. https://doi.org/10.1016/j.jecp.2015.12.001

Callanan, M. A. (1990). Parents' descriptions of objects: Potential data for children's inferences about category principles. Cognitive Development, 5(1), 101-122. https://doi.org/10.1016/0885-2014(90)90015-L

Carlson, G. N. (1977). A unified analysis of the English bare plural. Linguistics and Philosophy, 1(3), 413-457. https://doi.org/10.1007/BF00353456 
Carlson, G. N., \& Pelletier, F. J. (1995). The generic book. Chicago, IL: University of Chicago Press.

Carstensen, A., Zhang, J., Heyman, G. D., Fu, G., Lee, K., \& Walker, C. M. (2019). Context shapes early diversity in abstract thought. Proceedings of the National Academy of Sciences, 201818365. https://doi.org/10.1073/pnas.1818365116

Chalik, L., Leslie, S. J., \& Rhodes, M. (2017). Cultural context shapes essentialist beliefs about religion. Developmental psychology, 53(6), 1178. https://doi.org/10.1111/cdev.12714

Choi, I., Nisbett, R. E., \& Norenzayan, A. (1999). Causal attribution across cultures: Variation and universality. Psychological Bulletin, 125(1), 47. https://10.1037/0033-2909.125.1.47

Cimpian, A., Arce, H. M. C., Markman, E. M., \& Dweck, C. S. (2007). Subtle linguistic cues affect children's motivation. Psychological Science, 18(4), 314-316. https://doi.org/10.1111/j.1467-9280.2007.01896.x

Cimpian, A., Brandone, A. C., \& Gelman, S. A. (2010). Generic statements require little evidence for acceptance but have powerful implications. Cognitive Science, 34(8), 1452-1482. https://doi.org/10.1111/j.1551-6709.2010.01126.x

Cimpian, A., \& Cadena, C. (2010). Why are dunkels sticky? Preschoolers infer functionality and intentional creation for artifact properties learned from generic language. Cognition, 117(1), 62-68. https://doi.org/10.1016/j.cognition.2010.06.011

Cimpian, A., \& Markman, E.M. (2011). The generic/nongeneric distinction influences how children interpret new information about social others. Child Development, 471-492. https://doi.org/10.1111/j.1467-8624.2010.01525.x

Cimpian, A., \& Salomon, E. (2014). The inherence heuristic: an intuitive means of making sense of the world, and a potential precursor to psychological essentialism. Behavioral and Brain Sciences, 37(5), 461-480. https://doi.org/10.1017/S0140525X13002197

Cimpian, A., \& Steinberg, O. D. (2014). The inherence heuristic across development: Systematic differences between children's and adults' explanations for everyday 
facts. Cognitive psychology, 75, 130-154.

https://doi.org/10.1016/j.cogpsych.2014.09.001

Clark, H. H. (1996). Using language. New York: Cambridge University Press.

Csibra, G., \& Gergely, G. (2009). Natural pedagogy. Trends in cognitive sciences, 13(4), 148153. https://doi.org/10.1016/j.tics.2009.01.005

Danovitch, J., and Keil, F., 2004. "Should You Ask a Fisherman or a Biologist?: Developmental Shifts in Ways of Clustering Knowledge." Child Development 75: 918-31. https://doi.org/10.1111/j.1467-8624.2004.00714.x

Deeb, I., Segall, G., Birnbaum, D., Ben-Eliyahu, A., \& Diesendruck, G. (2011). Seeing isn't believing: The effect of intergroup exposure on children's essentialist beliefs about ethnic categories. Journal of Personality and Social Psychology, 101(6), 1139. https://doi.org/10.1037/a0026107

Diesendruck, G., Goldfein-Elbaz, R., Rhodes, M., Gelman, S., \& Neumark, N. (2013). Crosscultural differences in children's beliefs about the objectivity of social categories. Child development, 84(6), 1906-1917. https://doi.org/10.1111/cdev.12108

Diesendruck, G., \& Haber, L. (2009). God's categories: The effect of religiosity on children's teleological and essentialist beliefs about categories. Cognition, 110(1), 100-114. https://doi.org/10.1016/j.cognition.2008.11.001

Diesendruck, G., \& Gelman, S. A. (1999). Domain differences in absolute judgments of category membership: Evidence for an essentialist account of categorization. Psychonomic Bulletin \& Review, 6(2), 338-346. http://dx.doi.org/10.3758/BF03212339

Donovan, B. M. (2014). Playing with fire? The impact of the hidden curriculum in school genetics on essentialist conceptions of race. Journal of Research in Science Teaching, 51(4), 462-496. https://doi.org/10.1002/tea.21138

Emmons, N. A., \& Kelemen, D. A. (2015). Young children's acceptance of within-species variation: Implications for essentialism and teaching evolution. Journal of Experimental 
Child Psychology, 139, 148-160. http://dx.doi.org/10.1016/j.jecp.2015.05.011

Estes, Z. (2003). Domain differences in the structure of artifactual and natural categories. Memory and Cognition, 31, 199-214. https://doi.org/10.3758/BF03194379

Estes, Z. (2004). Confidence and gradedness in semantic categorization: Definitely somewhat artifactual, maybe absolutely natural. Psychonomic Bulletin and Review, 11, 1041-1047. https://doi.org/10.3758/BF03196734

Everett, D. L. (2009). Pirahã culture and grammar: A response to some criticisms. Language, 85(2), 405-442. https://doi.org/10.1353/lan.0.0104

Fast, A. A., \& Olson, K. R. (2018). Gender development in transgender preschool children. Child development, 89(2), 620-637. https://doi.org/10.1111/cdev.12758

Ferguson, B., \& Lew-Williams, C. (2016). Communicative signals support abstract rule learning by 7-month-old infants. Scientific reports, 6, 25434. https://doi.org/10.1038/srep25434

Ferry, A. L., Hespos, S. J., \& Waxman, S. R. (2010). Categorization in 3-and 4-month-old infants: an advantage of words over tones. Child development, 81(2), 472-479. https://doi.org/10.1111/j.1467-8624.2009.01408.x

Foster-Hanson, E., Cimpian, A., Leshin, R. A., \& Rhodes, M. (2018). Asking children to "be helpers" can backfire after setbacks. Child development. https://doi.org/10.1111/cdev.13147

Foster-Hanson, E., Leslie, S., \& Rhodes, M. (2019, January 20). Speaking of kinds: How generic language shapes the development of category representations. https://doi.org/10.31234/osf.io/28qf7

French, J. A., Menendez, D., Herrmann, P. A., Evans, E. M., \& Rosengren, K. S. (2018). Cognitive constraints influence an understanding of life-cycle change. Journal of experimental child psychology, 173, 205-221. https://doi.org/10.1016/j.jecp.2018.03.018

Fulkerson, A. L., \& Waxman, S. R. (2007). Words (but not Tones) Facilitate Object Categorization: Evidence From 6- and 12-Month-Olds. Cognition, 105(1), 218-228. 
https://doi.org/10.1016/j.cognition.2006.09.005

Gelman, S. A. (1988). The development of induction within natural kind and artifact categories. Cognitive psychology, 20(1), 65-95. https://doi.org/10.1016/00100285(88)90025-4

Gelman, S. A. (2003). The essential child: Origins of essentialism in everyday thought. Oxford University Press. https://doi.org/10.1093/acprof:oso/9780195154061.001.0001

Gelman, S. A. (2004). Psychological essentialism in children. Trends in cognitive sciences, 8(9), 404-409. https://doi.org/10.1016/j.tics.2004.07.001

Gelman, S. A. (2009). Learning from others: Children's construction of concepts. Annual review of psychology, 60, 115-140. https://doi.org/10.1146/annurev.psych.59.103006.093659

Gelman, R. (1990). First principles organize attention to and learning about relevant data: Number and the animate-inanimate distinction as examples. Cognitive science, 14(1), 79-106. https://doi.org/10.1207/s15516709cog1401_5

Gelman, S. A., \& Coley, J. D. (1990). The importance of knowing a dodo is a bird: Categories and inferences in 2-year-old children. Developmental Psychology, 26(5), 796-804. https://doi.org/10.1037/0012-1649.26.5.796

Gelman, S. A., Collman, P., \& Maccoby, E. E. (1986). Inferring properties from categories versus inferring categories from properties: The case of gender. Child Development, 396-404. https://www.jstor.org/stable/1130595

Gelman, S. A., Goetz, P. J., Sarnecka, B. S., \& Flukes, J. (2008). Generic language in parentchild conversations. Language Learning and Development, 4(1), 1-31. https://doi.org/10.1080/15475440701542625

Gelman, S. A., \& Heyman, G. D. (1999). Carrot-eaters and creature-believers: The effects of lexicalization on children's inferences about social categories. Psychological Science, 10(6), 489-493. https://doi.org/10.1111/1467-9280.00194

Gelman, S. A., \& Kremer, K. E. (1991). Understanding natural cause: Children's explanations of 
how objects and their properties originate. Child Development, 62(2), 396-414. https://doi.org/10.1111/j.1467-8624.1991.tb01540.x

Gelman, S. A., \& Markman, E. M. (1986). Categories and induction in young children. Cognition, 23(3), 183-209. https://doi.org/10.1016/0010-0277(86)90034-X

Gelman, S. A., \& O'Reilly, A. W. (1988). Children's inductive inferences within superordinate categories: The role of language and category structure. Child development, 876-887. https://doi.org/10.2307/1130255

Gelman, S. A., \& Raman, L. (2003). Preschool children use linguistic form class and pragmatic cues to interpret generics. Child Development, 24, 308-325. https://doi.org/10.1111/1467-8624.00537

Gelman, S. A., \& Rhodes, M. (2012). Two-thousand years of stasis. In Evolution challenges (pp. 3-21). Oxford University Press. https://doi.org/10.1093/acprof:oso/9780199730421.003.0001

Gelman, S. A., Sánchez Tapia, I., \& Leslie, S.-J. (2016). Memory for generic and quantified sentences in Spanish-speaking children and adults. Journal of Child Language, 43(6), 1231-1244. https://doi.org/10.1017/s0305000915000483

Gelman, S. A., Taylor, M. G., \& Nguyen, S. P. (2004). Mother-child conversations about gender: Understanding the acquisition of essentialist beliefs. Monographs of the Society for Research in Child Development, 69(1), 93-118. https://doi.org/10.1111/j.0037976X.2004.00279.x

Gelman, S. A., Ware, E. A., \& Kleinberg, F. (2010). Effects of generic language on category content and structure. Cognitive Psychology, 61(3), 273-301. https://doi.org/10.1016/j.cogpsych.2010.06.001

Gelman, S. A., Ware, E. A., Manczak, E. M., \& Graham, S. A. (2013). Children's sensitivity to the knowledge expressed in pedagogical and nonpedagogical contexts. Developmental Psychology, 49(3), 491. https://doi.org/10.1037/a0027901 
Gelman, S. A., \& Wellman, H. M. (1991). Insides and essences: Early understandings of the non-obvious. Cognition, 38(3), 213-244. https://doi.org/10.1016/0010-0277(91)90007-Q

Gentner, D. (1983). Structure-mapping: A theoretical framework for analogy. Cognitive Science, 7(2), 155-170. https://doi.org/10.1016/S0364-0213(83)80009-3

Gentner, D. (2005). The development of relational category knowledge. In Building object categories in developmental time (pp. 263-294). Psychology Press.

Goldin-Meadow, S., Gelman, S. A., \& Mylander, C. (2005). Expressing generic concepts with and without a language model. Cognition, 96(2), 109-126. https://doi.org/10.1016/j.cognition.2004.07.003

Gopnik, A., \& Wellman, H. M. (2012). Reconstructing constructivism: Causal models, Bayesian learning mechanisms, and the theory theory. Psychological Bulletin, 138(6), 1085-1108. https://doi.org/10.1037/a0028044

Graham, S. A., Nayer, S. L., \& Gelman, S. A. (2011). Two-year-olds use the generic/nongeneric distinction to guide their inferences about novel kinds. Child Development, 82(2), 493507. https://doi.org/10.1111/j.1467-8624.2010.01572.x

Grice, H. (1975). Logic and conversation. In P. Cole \& J. L. Morgan (Eds.), Syntax and semantics (Vol. 3, pp. 41-58). New York, NY: Academic Press.

Harris, P. L., \& Koenig, M. A. (2006). Trust in testimony: How children learn about science and religion. Child Development, 77(3), 505-524. https://doi.org/10.1111/j.14678624.2006.00886.x

Hirschfeld, L. A. (1996). Race in the making: Cognition, culture, and the child's construction of human kinds. Cambridge, MA: MIT Press.

Hollander, M. A., Gelman, S. A., \& Star, J. (2002). Children's interpretation of generic noun phrases. Developmental Psychology, 38(6), 883-894. https://doi.org/10.1037/00121649.38.6.883

Horn, L. (1984). Toward a new taxonomy for pragmatic inference: Q-based and r-based 
implicature. In Schiffrin, D. (Ed.), Meaning, form, and use in context: Linguistic applications (pp 11-42). Washington, D.C.: Georgetown University Press.

Hussak, L. J., \& Cimpian, A. (2018). Memory accessibility shapes explanation: Testing key claims of the inherence heuristic account. Memory \& cognition, 46(1), 68-88. https://doi.org/10.3758/s13421-017-0746-8

Jaswal, V. K. (2010). Believing what you're told: Young children's trust in unexpected testimony about the physical world. Cognitive psychology, 61(3), 248-272. https://doi.org/10.1016/j.cogpsych.2010.06.002

Jaswal, V. K., Lima, O. K., \& Small, J. E. (2009). Compliance, conversion, and category induction. Journal of Experimental Child Psychology, 102(2), 182-195. https://doi.org/10.1016/j.jecp.2008.04.006

Kalish, C. (1998). Natural and artifactual kinds: Are children realists or relativists about categories? Developmental Psychology, 34(2), 376-391.

Kalish, C. (1998). Reasons and causes: children's understanding of conformity to social rules and physical laws. Child Development, 69(3), 706-720. https://doi.org/10.1111/j.14678624.1998.tb06238.x

Kalish, C. W. (2002). Children's predictions of consistency in people's actions. Cognition, 84(3), 237-265. https://doi.org/10.1016/S0010-0277(02)00052-5

Kalish, C. W., \& Lawson, C. A. (2008). Development of social category representations: Early appreciation of roles and deontic relations. Child Development, 79(3), 577-593. https://doi.org/10.1111/j.1467-8624.2008.01144.x

Keil, F. C. (1989). Concepts, kinds, and conceptual development. MIT Press.

Kinzler, K. D., \& Dautel, J. B. (2012). Children's essentialist reasoning about language and race. Developmental Science, 15(1), 131-138. https://doi.org/10.1111/j.14677687.2011.01101.x

Kripke, S. A. (1972). Naming and necessity. In Semantics of natural language (pp. 253-355). 
Springer, Dordrecht.

Leslie, S. J. (2008). Generics: Cognition and acquisition. Philosophical Review, 117(1), 1-47. https://doi.org/10.1215/00318108-2007-023

Leslie, S. J. (2013). Essence and natural kinds: When science meets preschooler intuition. Oxford Studies in Epistemology, 4, 108-166. https://doi.org/10.1093/acprof:oso/9780199672707.003.0005

Leslie, S. J. (2014). Carving up the social world with generics. Oxford studies in experimental philosophy, 1, 208-232.

Leslie, S. J., Khemlani, S., \& Glucksberg, S. (2011). Do all ducks lay eggs? The generic overgeneralization effect. Journal of Memory and Language, 65(1), 15-31. https://doi.org/10.1016/j.jml.2010.12.005

Lowell, B., Mustain, P., Ortenzi, K., \& Warner, K. (2015). One name, one fish: why seafood names matter. Oceana, 1-12. http://usa.oceana.org/sites/default/files/onenameonefishreport.pdf

Lynch, E. B., Coley, J. D., \& Medin, D. L. (2000). Tall is typical: Central tendency, ideal dimensions, and graded category structure among tree experts and novices. Memory \& Cognition, 28(1), 41-50. https://doi.org/10.3758/BF03211575

Lyons, J. (1977). Semantics (Vol. 2). Cambridge university press.

Mallet, J. (2008). Hybridization, ecological races and the nature of species: empirical evidence for the ease of speciation. Philosophical Transactions of the Royal Society B: Biological Sciences, 363(1506), 2971-2986. https://doi.org/10.1098/rstb.2008.0081

Malt, B. C. (1990). Features and beliefs in the mental representation of categories. Journal of Memory and Language, 29(3), 289-315. https://doi.org/10.1016/0749-596X(90)90002-H

Mandalaywala, T. M., Amodio, D. M., \& Rhodes, M. (2018). Essentialism promotes racial prejudice by increasing endorsement of social hierarchies. Social Psychological and Personality Science, 9(4), 461-469. https://doi.org/10.1177/1948550617707020 
Mandalaywala, T. M., Ranger-Murdock, G., Amodio, D. M., \& Rhodes, M. (2019). The nature and consequences of essentialist beliefs about race in early childhood. Child development, 90(4), e437-e453. https://doi.org/10.1111/cdev.13008

Mannheim, B., Gelman, S. A., Escalante, C., Huayhua, M., \& Puma, R. (2010). A developmental analysis of generic nouns in Southern Peruvian Quechua. Language Learning and Development, 7(1), 1-23. https://doi.org/10.1080/15475441003635620

Mayr, E. (1982). The growth of biological thought: Diversity, evolution, and inheritance. Harvard University Press.

Medin, D. L., Ross, N., Atran, S., Burnett, R. C., \& Blok, S. V. (2002). Categorization and reasoning in relation to culture and expertise. In Psychology of learning and motivation (Vol. 41, pp. 1-41). Academic Press. https://doi.org/10.1016/S00797421(02)80003-2

Medin, D. L., Ross, N. O., Atran, S., Cox, D., Coley, J., Proffitt, J. B., \& Blok, S. (2006). Folkbiology of freshwater fish. Cognition, 99(3), 237-273. https://doi.org/10.1016/j.cognition.2003.12.005

Medin, D., Waxman, S., Woodring, J., \& Washinawatok, K. (2010). Human-centeredness is not a universal feature of young children's reasoning: Culture and experience matter when reasoning about biological entities. Cognitive Development, 25(3), 197-207. https://doi.org/10.1016/J.COGDEV.2010.02.001

Mill, J. S. (1884). A system of logic, ratiocinative and inductive: Being a connected view of the principles of evidence and the methods of scientific investigation (Vol. 1). Longmans, green, and Company.

Moty, K., \& Rhodes, M. (2019, August 29). The unintended consequences of the things we say: What generics communicate to children about unmentioned categories. https://doi.org/10.31234/osf.io/zkjyr

Murphy, G. L., \& Medin, D. L. (1985). The role of theories in conceptual 
coherence. Psychological review, 92(3), 289. https://doi.org/10.1037/0033295X.92.3.289

Noyes, A., \& Keil, F. C. (2017). Revising deference: Intuitive beliefs about category structure constrain expert deference. Journal of Memory and Language, 95, 68-77. https://doi.org/10.1016/j.jml.2017.02.003

Noyes, A., \& Dunham, Y. (2019, April 16). Separating kindhood from naturalness: When two dimensions are better than one. https://doi.org/10.31234/osf.io/q3zg5

Pappas, A., \& Gelman, S. A. (1998). Generic noun phrases in mother-child conversations. Journal of Child Language, 25, 19-33. https://doi.org/10.1017/S0305000997003292

Plato, \& Grube, G. M. A. (1974). The Republic. Hackett Publishing.

Prasada, S., \& Dillingham, E. M. (2009). Representation of principled connections: A window onto the formal aspect of common sense conception. Cognitive Science, 33(3), 401448. https://doi.org/10.1111/j.1551-6709.2009.01018.x

Premack, D. (1990). The infant's theory of self-propelled objects. Cognition, 36(1), 1-16. https://doi.org/10.1016/0010-0277(90)90051-K

Prentice, D. A., \& Miller, D. T. (2007). Psychological essentialism of human categories. Current Directions in Psychological Science, 16(4), 202-206. https://doi.org/10.1111/j.14678721.2007.00504.x

Putnam, H. (1973). Explanation and reference. In Conceptual change (pp. 199-221). Springer, Dordrecht.

Putnam, H. (1975a). The meaning of 'meaning'. Philosophical Papers, 2.

Quine, W. V. (1977). Intensions revisited. Midwest Studies in Philosophy, 2, 5-11.

Rafetseder, E., Cristi-Vargas, R., \& Perner, J. (2010). Counterfactual reasoning: Developing a sense of "nearest possible world". Child Development, 81(1), 376-389. https://doi.org/10.1111/j.1467-8624.2009.01401.x

Rhodes, M., \& Gelman, S. A. (2009a). A developmental examination of the conceptual structure 
of animal, artifact, and human social categories across two cultural contexts. Cognitive psychology, 59(3), 244-274. https://doi.org/10.1016/j.cogpsych.2009.05.001

Rhodes, M., \& Gelman, S. A. (2009b). Five-year-olds' beliefs about the discreteness of category boundaries for animals and artifacts. Psychonomic Bulletin \& Review, 16(5), 920-924. https://doi.org/10.3758/PBR.16.5.920

Rhodes, M., Gelman, S. A., \& Karuza, J. C. (2014). Preschool ontology: The role of beliefs about category boundaries in early categorization. Journal of Cognition and Development, 15(1), 78-93. https://doi.org/10.1080/15248372.2012.713875

Rhodes, M., Leslie, S.J., Bianchi, L., \& Chalik, L. (2017). The role of generic language in the early development of social categorization. Child Development. https://doi.org/10.1111/cdev.12714

Rhodes, M., Leslie, S.J., Saunders, K., Dunham, Y., \& Cimpian, A. (2017). How does social essentialism affect the development of inter-group relations? Developmental Science. https://doi.org/10.1111/desc.12509

Rhodes, M., Leslie, S., \& Tworek, C. M. (2012). Cultural transmission of social essentialism. PNAS Proceedings of the National Academy of Sciences of the United States of America, 109(34), 13526-13531. https://doi.org/10.1073/pnas.1208951109

Rhodes, M., \& Mandalaywala, T. M. (2017). The development and developmental consequences of social essentialism. Wiley Interdisciplinary Reviews: Cognitive Science, 8(4), e1437. https://doi.org/10.1002/wcs.1437

Richland, L. E., Morrison, R. G., \& Holyoak, K. J. (2006). Children's development of analogical reasoning: Insights from scene analogy problems. Journal of experimental child psychology, 94(3), 249-273. https://doi.org/10.1016/j.jecp.2006.02.002

Rips, L. J. (1975). Inductive judgments about natural categories. Journal of Verbal Learning and Verbal Behavior, 14(6), 665-681. https://doi.org/10.1016/S0022-5371(75)80055-7

Roberts, S. O., \& Gelman, S. A. (2016). Can White children grow up to be Black? Children's 
reasoning about the stability of emotion and race. Developmental Psychology, 52(6), 887-893. https://doi.org/10.1037/dev0000132

Roberts, S. O., Ho, A. K., \& Gelman, S. A. (2017). Group presence, category labels, and generic statements influence children to treat descriptive group regularities as prescriptive. Journal of Experimental Child Psychology, 158, 19-31. https://doi.org/10.1016/J.JECP.2016.11.013

Roberts, S. O., Ho, A. K., Rhodes, M., \& Gelman, S. A. (2017). Making boundaries great again: Essentialism and support for boundary-enhancing initiatives. Personality and Social Psychology Bulletin, 43(12), 1643-1658. https://doi.org/10.1177/0146167217724801

Ross, N., Medin, D., Coley, J. D., \& Atran, S. (2003). Cultural and experiential differences in the development of folkbiological induction. Cognitive Development, 18(1), 25-47. https://doi.org/10.1016/S0885-2014(02)00142-9

Rothbart, M., \& Taylor, M. (1992). Category labels and social reality: Do we view social categories as natural kinds? In G. R. Semin \& K. Fiedler (Eds.), Language, interaction and social cognition (p. 11-36). Sage Publications, Inc.

Schwartz, S. P. (1979). Natural kind terms. Cognition, 7(3), 301-315. https://doi.org/10.1016/0010-0277(79)90003-9

Segall, G., Birnbaum, D., Deeb, I., \& Diesendruck, G. (2015). The intergenerational transmission of ethnic essentialism: How parents talk counts the most. Developmental Science, 18: 543-55. https://doi.org/10.1111/desc.12235

Short, S. D., \& Hawley, P. H. (2015). The effects of evolution education: examining attitudes toward and knowledge of evolution in college courses. Evolutionary Psychology, 13(1), 147470491501300105. https://doi.org/10.1177/147470491501300105

Shtulman, A. (2017). Scienceblind: why our intuitive theories about the world are so often wrong. Basic Books.

Shtulman, A., \& Calabi, P. (2013). Tuition vs. intuition: Effects of instruction on naive theories of 
evolution. Merrill-Palmer Quarterly, 59(2), 141-167.

https://doi.org/10.13110/merrpalmquar1982.59.2.0141

Shtulman, A., \& Schulz, L. (2008). The relation between essentialist beliefs and evolutionary reasoning. Cognitive Science, 32(6), 1049-1062.

https://doi.org/10.1080/03640210801897864

Smyth, K., Feeney, A., Eidson, R. C., \& Coley, J. D. (2017). Development of essentialist thinking about religion categories in Northern Ireland (and the United States). Developmental Psychology, 53(3), 475-496. https://doi.org/10.1037/dev0000253

Spelke, E. S., Phillips, A., \& Woodward, A. L. (1995). Infants' knowledge of object motion and human action. In D. Sperber, D. Premack, \& A. J. Premack (Eds.), Symposia of the Fyssen Foundation. Causal cognition: A multidisciplinary debate (p. 44-78). Clarendon Press/Oxford University Press.

Stewart, J. (1984). Object motion and the perception of animacy. Presented at the meeting of the Psychonomic Society, San Antonio, TX, November 1984.

Swiney, L., Bates, D. G., \& Coley, J. D. (2018). Cognitive Constraints Shape Public Debate on the Risks of Synthetic Biology. Trends in biotechnology, 36(12), 1199-1201. https://doi.org/10.1016/j.tibtech.2018.09.002

Tardif, T., Gelman, S. A., Fu, X., \& Zhu, L. (2012). Acquisition of generic noun phrases in Chinese: Learning about lions without an '-s'. Journal of child language, 39(1), 130-161. https://doi.org/10.1017/S0305000910000735

Taverna, A. S., Medin, D. L., \& Waxman, S. R. (2016). "Inhabitants of the earth": Reasoning about folkbiological concepts in Wichi children and adults. Early Education and Development, 27(8), 1109-1129. https://doi.org/10.1080/10409289.2016.1168228

Taylor, M.G. (1996). The development of children's beliefs about social and biological aspects of gender differences. Child Development, 67: 1555-1571. DOI:10.1111/j.14678624.1996.tb01814.x 
Taylor, M. G., Rhodes, M., \& Gelman, S. A. (2009). Boys will be boys; cows will be cows: Children's essentialist reasoning about gender categories and animal species. Child Development, 80(2), 461-481. https://doi.org/10.1111/j.1467-8624.2009.01272.x

Tessler, M. H., \& Goodman, N. D. (2019). The language of generalization. Psychological Review, 126(3), 395. https://doi.org/10.1037/rev0000142

VanderBorght, M., \& Jaswal, V. K. (2009). Who knows best? Preschoolers sometimes prefer child informants over adult informants. Infant and Child Development: An International Journal of Research and Practice, 18(1), 61-71. https://doi.org/10.1002/icd.591

Vasilyeva, N., Gopnik, A., \& Lombrozo, T. (2018). The development of structural thinking about social categories. Developmental Psychology. https://doi.org/10.1037/dev0000555

Vygotsky, L. S. (1962). Language and thought. Massachusetts Institute of Technology Press, Ontario, Canada.

Waxman, S., Medin, D., \& Ross, N. (2007). Folkbiological reasoning from a cross-cultural developmental perspective: early essentialist notions are shaped by cultural beliefs. Developmental Psychology, 43(2), 2. https://doi.org/10.1037/0012-1649.43.2.294

Wellman, H.M., \& Gelman, S.A. (1992). Cognitive development: Foundational theories of core domains. Annual Review of Psychology, 43, 337-375.

Williams, M.J., \& Eberhardt J.L. (2008) Biological conceptions of race and the motivation to cross racial boundaries. Journal of Personality and Social Psychology, 94:1033-1047. https://doi.org/10.1037/0022-3514.94.6.1033

Wilson, R. A. (1999). Realism, essence, and kind: Resuscitating species essentialism. Species: New interdisciplinary essays, 187-207.

Wilson, R. A., \& Keil, F. (1998). The shadows and shallows of explanation. Minds and machines, 8(1), 137-159.

$\mathrm{Xu}, \mathrm{F}$. (2002). The role of language in acquiring object kind concepts in infancy. Cognition, 85(3), 223-250. https://doi.org/10.1016/S0010-0277(02)00109-9 
